\title{
Human Capital Development and Economic Growth in Bangladesh
}

\author{
Md Niaz Murshed Chowdhury ${ }^{1}$, Mohammed Jashim Uddin ${ }^{2}$, Nezum Uddin ${ }^{2}$, Shamim Uddin $^{3}$ \\ ${ }^{1}$ Department of Economics, University of Nevada, Reno, USA \\ ${ }^{2}$ Department of Economics and Banking, International Islamic University Chittagong, Chittagong, Bangladesh \\ ${ }^{3}$ Economic Research, the Central Bank of Bangladesh, Dhaka, Bangladesh
}

Email address:

niaz060707@gmail.com(Md N. M. Chowdhury)

\section{To cite this article:}

Md Niaz Murshed Chowdhury, Mohammed Jashim Uddin, Nezum Uddin, Shamim Uddin. Human Capital Development and Economic Growth in Bangladesh. Journal of World Economic Research. Vol. 7, No. 2, 2018, pp. 52-63. doi: 10.11648/j.jwer.20180702.12

Received: January 20, 2018; Accepted: May 19, 2018; Published: June 11, 2018

\begin{abstract}
Human Capital is an integral part of any country's development and economic growth has human capital as an important factor. This study empirically evaluates the relevance of human capital development on the growth of the economy pin pointing the relationship that exists between them. In this study, unit root test, Johansson co integration test and ordinary least square (OLS) technique are done. The GDP per capita was used as a proxy for economic growth; Per Capital Gross Domestic Product, primary school enrolment, Secondary school enrollment, tertiary school enrollment, public expenditure on education and health, life expectancy, gross capital formation. From the analysis, it was deduced that there is a strong positive relationship between human capital development and economic growth. Life expectancy is found to be most important variable in this model as it has large impact on economic growth in Bangladesh. Recent time tertiary education has significantly affected the economic growth instead of secondary education. Workable policies should be put in place to bring about an overall economic growth. Expenditures on health and public education should be utilized effectively and efficiently so that the country would experience quality health care services and quality educational system.
\end{abstract}

Keywords: Human Capital, GDP, Economic Growth, Ordinary Least Squares, Johansson Co-integration, Unit Root Test

\section{Introduction}

The world today is very different from the one which experienced the two world wars. During the second half of the twentieth century, considerable advancements in science and technology, along with the establishment of broadly based governments and strengthening of institutions, have led to significant socio-economic progress and improvement in the lives of a large number of people in many countries. However, there are still many others among us who are lagging behind. The current reality in the Asian region is the existence of significant differences in the state of economic development among countries.

Human capital as defined by (Schultz, 1993) is the key element in improving firms' asset and employees in order to improve productivity as well as sustain competitive advantage. Human capital becomes a tool for competitive advantage since it involves the process of training, knowledge acquisition (education), initiatives and so on, all these are geared towards skill acquisition. Human capital development is human centered because its major concern is on human empowerment that would lead to active participation. According to OECD (2001), human capital is concerned with knowledge, skills competitiveness and attributes embedded in an individual that facilitates the creation of personal, social and economic wellbeing. In order to achieve positive economic growth in Bangladesh, human capital development should be considered as an integral and important factor for economic growth. A major challenge facing the global community and Bangladesh at large is how to achieve sustainable development. The three pillars of sustainable development cannot be achieved if human capital development doesn't come to play as an integral part.

Human resource development is an integral part of development agenda. The Government of Bangladesh has been implementing various programs in the sectors related to human resource development like education and technology; 
health and family welfare; women and children; social welfare; youth and sports development; culture and labour and employment. In order to create efficient and competent human resources by way of upgrading the quality of education and creating enrolment opportunities at secondary, higher secondary, technical and all levels of higher education, various programs have been adopted. In addition, the Government has declared a comprehensive National Education Policy 2010 which will cater to the needs of the country. The ratio of female teachers has increased from 21 percent in 1991 to 61.7 percent following the policy of appointing 60 percent female teachers in government primary schools. In order to ensure eradication of illiteracy by 2014 , emphasis has been given on school enrollment, pre-school education, awarding of stipends and scaling up teacherstudent contact hours. After Sri Lanka, Bangladesh has earned a rare distinction among the least developed countries in the field of education at primary and secondary levels by ensuring gender balance. A substantial progress has been made in the health sector of the country as the government has given priority to the health, nutrition and population sector which is consistent with targets set out in the Millennium Development Goals. Mortality and fertility rates have decreased. Significant development has been taking place in reduction of neonatal deaths. Average life expectancy has increased from 64.2 in 2001 to 71 in 2013. The rate of malnutrition has also reduced. Steps have been taken to make these achievements sustainable through an integrated sector programs titled Health, Population and Nutrition Sector Development Programs (HPNSDP). To educate women of the country and to develop them as efficient work force and also to ensure their active participation in the mainstream of national development activities, the Government has recently declared the National Women Development Policy 2011. In addition, the National Children Policy, 2011 has been adopted to ensure the welfare of children and to protect their interest and rights.

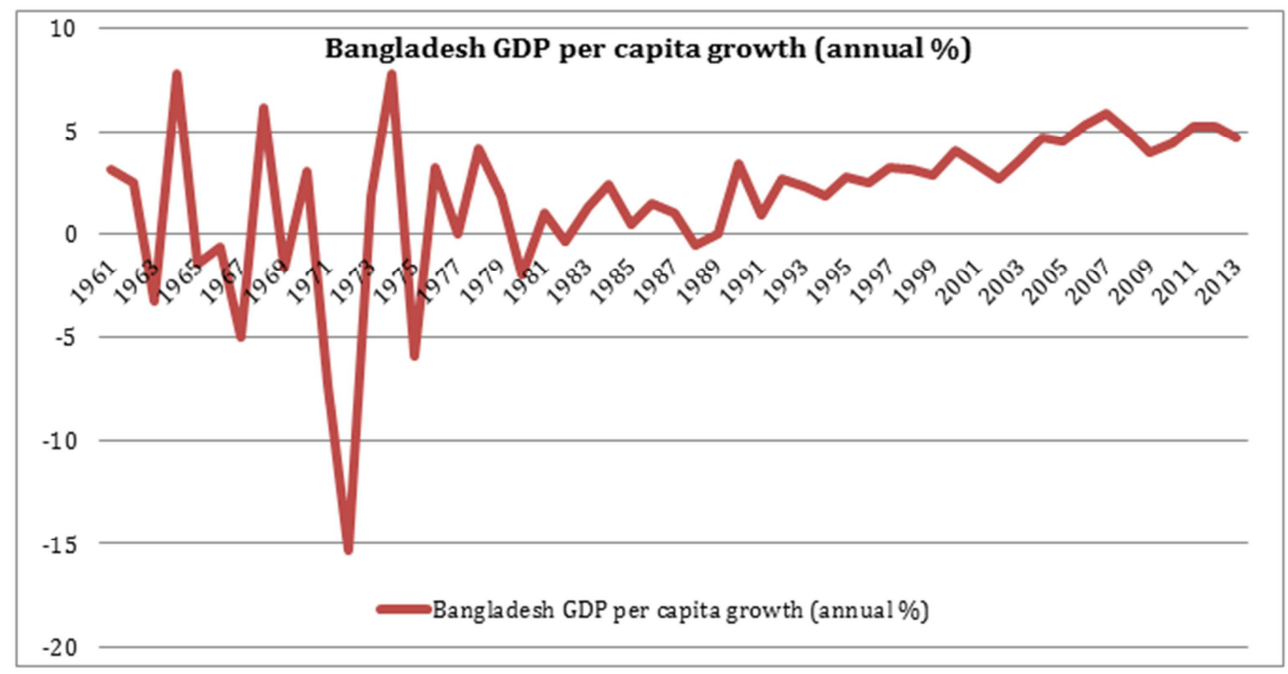

Figure 1. Bangladesh GDP per capita growth (annual \%).

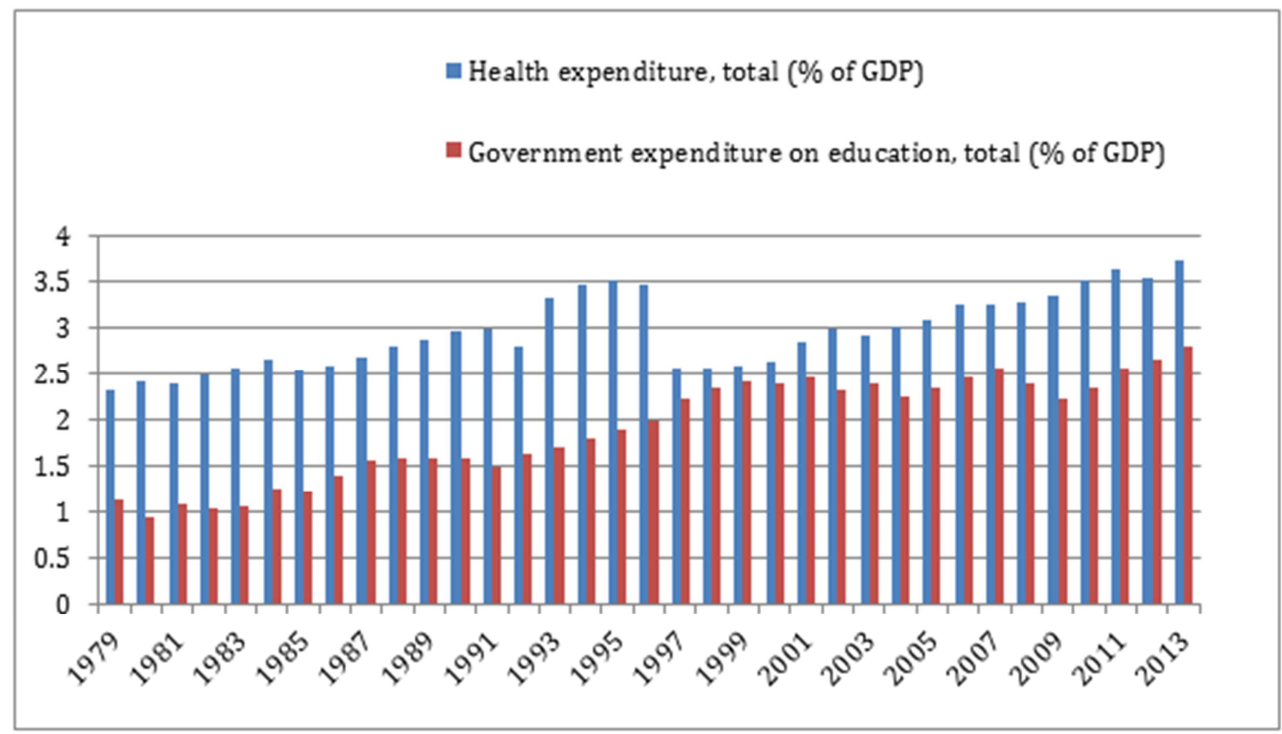

Figure 2. Comparisons between Health and Education Expenditure. 


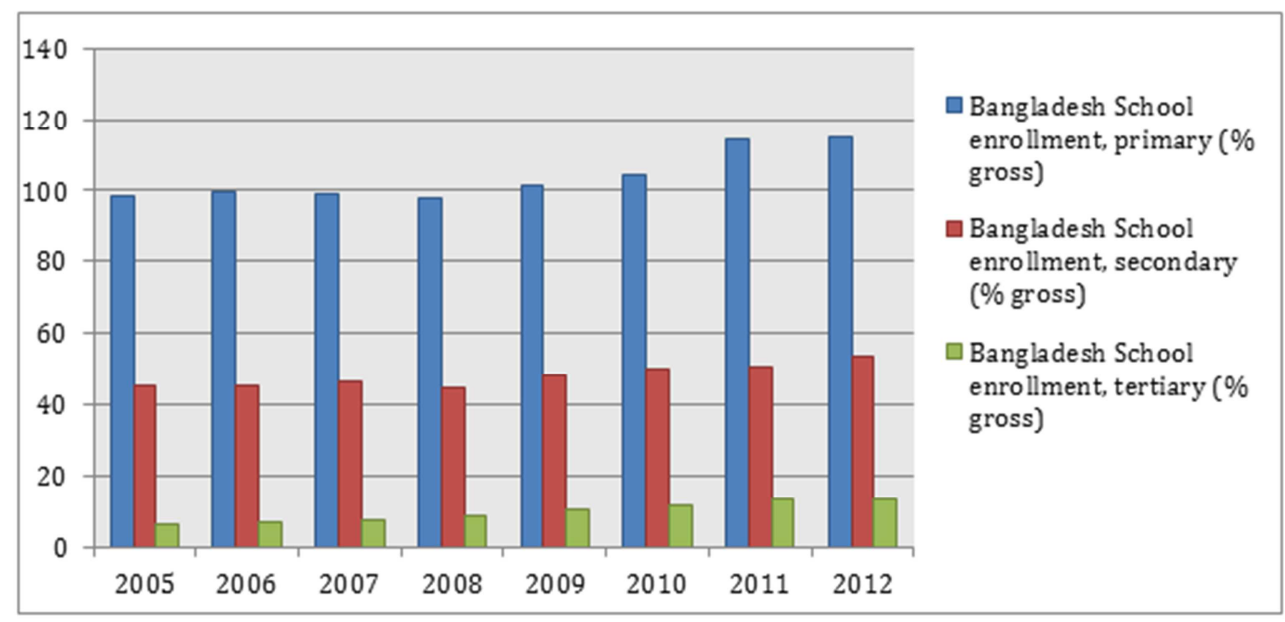

Figure 3. Health expenditure is always higher compared to education expenditure In Bangladesh.

The above graph shows that there was an up and down trend between the period of 1961 and 1970; this is because of prelibation periods, and there was no permanent government between these times. It indicates that West Pakistan government had a lowest investment for the East Pakistan and it also shows that they exploited the East Pakistan. They didn't care about the development of East Pakistan. In 1971 to 1973 there was a drastically fall in GDP per capita growth rate because of the liberation. This analysis found an upward trend which indicates there was a consistent GDP per capita growth from 1992 to 2007 periods of time.

In education like primary secondary and tertiary level, we see an upward trend. Primary enrollment rate is higher than others. The coverage of social security has been expanded to ensure welfare of the poor of the country. As a result, investment in social sectors to develop the human resources has also increased. Social sectors contribute to the higher value addition to the economy by enhancing production, income and opportunities of employment. Due to this overriding importance, all UN member countries in the World Summit on Social Development (WSSD), held in Copenhagen in 1995, reached a consensus that each member country should allocate at least 20 percent of the public outlay for social sector. Following the declaration, Bangladesh has been spending over 20 percent of the total public outlay in the social sector. The Government considers health and education sector as foundation for human development. Accordingly the highest allocation was given to education sector in the previous fiscal year. Similarly adequate provision has been made for the health sector also.

In order to justify further the critical importance given to the development of human capital in Bangladesh, The main objective of this study is to investigate the relationship human capital development and economic growth of Bangladesh. The specific objectives are: To examine the pattern and trend of human capital development in Bangladesh. Second is to estimate the relationship between economic growth and human capital development in Bangladesh and finally to suggest the policy implication and recommendation for future research.
This investigation will test the following propositions as denoted by the null (Ho) and alternative (Hi) hypothesis, Ho: there is no is positive relationship between economic growth and Human capital development in Bangladesh. Hi: there is positive relationship between economic growth and Human capital development in Bangladesh. Government, NGO and other private organizations are working to develop human resources to ensure that Bangladesh can compete in local and global markets. Academicians, researchers, the Government, decision-makers, and others planners and administrators agree that human resources are the most vital factor in the industrial and agricultural development of Bangladesh. Human development can reduce inequality and it also accelerates the poverty reduction through human development. Formal training programs (business education, technical education, technical training, vocational training and other training programs) will play a key role in the development of its human resources. A survey of the existing literature reveals that little research has been done on this topic.

\section{Review of the Literature}

Human capital refers to the stock of competencies, skills, knowledge and personalities attribute embodies in individuals which facilitate their ability to perform labour for the creation of personal, economic and social vale (OECD, 2001), labour is one of the factors of production and can also be referred to as workforce. One of the major investments on human capital is education and that iswhy Schultz (1961) and many other American economists in the early 60s found that investment on education is one of the significant factors responsible for the swift growth of the American economy, they pointed that a dollar investment on education brings greater increase in their country's GDP relative to a dollar expenditure on physical capital like dams, road, street light etc. (Ifeoma C, 2013).

(Mankiw, 1992) pointed out a significant role of human capital measured by the secondary school enrollment rates. (Galbraith, 1996) emphasized on human capital instead of 
more capital investment. They suggest that invest on human capital via education, training, medical treatment and said one's output depends partly on the rate of return on human capital one owns. One study found positive correlation with economic growth and development when they invested on education (Olaniyan, 2008) high public investment level in Bangladesh together with improvement in institutional surroundings would be beneficial for economic growth (Md. Mahi Uddin, 2015). Literacy rate is positively related to per capita output growth and using school enrolment, they found out that the sign of the coefficients were statistically significant in the Zimbabwean economy, the incorporated human capital variables such as school enrolments into the standard growth model and found a very strong long run relationship between human capital investment and economic growth (Ojo Oladeji, 1995). (Garba, 2002) found that there are positive correlation between educational attainment and economic growth and development carrying out a crosscountry analysis using regressions analysis.

(Adebayo (2009) concluded that human resources of any nation are the key factor of its economic and social development instead of its physical, capital and material resources. They found Human capital is pretty much similar to "physical means of production". The main causes of unemployment for tertiary level graduates were actually the absence of association between higher education and the labor market (Abosetegn, 2000). Bangladesh should find out any option of debt cancellation and must increase human development and more infrastructure development. It is also recommended that debt management should be effective and fair, and Exports, FDI and Remittances are helpful for the growth of Bangladesh (Yeasmin \& Chowdhury, 2014). (Ifeoma C, 2013) conduct a research and their study evaluates the relevance of human capital development on the growth of the economy pin pointing the relationship that exists between them where they used OLS technique. They found there is a strong positive relationship between human capital development and economic growth. Effective utilization of health and public education expenditure and workable policies are needed so that the country would experience quality health care services and quality educational system. (Sajid Ali, 2012) uses time series data to examines the role of human capital formation in economic growth in Pakistan. They found that education enrollment, health and physical capital are important to boost the economic growth in Pakistan. Human capital, fixed capital and employed labor force affect the GDP and result in unidirectional and non-unidirectional causality. Finally, they concluded that education enrollment index, gross fixed capital formation and Gini coefficient have positive and significant impact on gross domestic product.

(Adelakun, 2011), used the theoretical and ordinary least square (OLS) to analyze the relationship using the GDP as proxy for economic growth; total government expenditure on education and health, and the enrolment pattern of tertiary, secondary and primary schools as proxy for human capital and found a strong positive relationship between human capital development and economic growth. That study recommended proper institutional framework and policy instrument to boost the overall growth of the economy. The connections between economic growth (EG) and human development (HD) form two chains, and cross-country regressions showed a significant relationship in both directions, with public expenditures on health and education (RANIS, 2000). (Bills, 2000) said education has a long run and significant relationship with growth. They suggested that progress in education standards affect the growth in the long run and would enhance the productivity.

(Taimur Sharif, 2013) constructed in light of two prominent endogenous growth models, ie, Lucas (1988) and Romer (1986, 1990), and a couple of econometric tests. In their research, the Engle-Granger cointegration tests have suggested a positive correlation between HRD activities and economic growth process of Bangladesh. They found investments in education have played a stimulating role and R\&D expenditures have made a weak but positive contribution in growth. They also found export as the accelerating growth factor that played an important role in Bangladesh's growth. The study (Wakeel A Isola, 2007; Wakeel A Isola, 2007) examined the contribution of different measures of human capital development to economic growth in Nigeria and used data from Nigeria and adopted the growth account model which specifies the growth of GDP as a function of labour and capital. The study found that both education and health components of human capital development are crucial to economic growth in Nigeria.

(Gazi Mahabubul Alam, 2009) showed that primary education contributes mainly for social development but secondary education have little contribution for economic development and argued Higher Education (HE) consumes a large portion of public and private fund to ensure economic development and contribution from HE is not satisfactory. This study also advocates an urgent need to conduct a broader study on this issue to make the education system more effective towards the development. (Risikat) used endogenous growth model to estimate the human capital formation and economic growth in Nigeria. He employed enrollment in the different levels of education, primary, secondary and tertiary as proxies for human capital and found long positive relationship between human capital formation and economic growth in Nigeria with a feedback mechanism. (Poças, 2014) uses a panel data model exclusively for developed countries for the 1980-2005 period. They found that health improvements have significant benefits on economic growth and therefore it should be considered as an important component of human capital along with education. They concluded that investing in individuals' education and health is important not only for an increasing wellbeing but also for a sustainable economic growth.

(RAUL RAMOS, 2012) tries to analyze the regional economic growth and human capital: the role of overeducation, Regional Studies using various indicators of human capital calculated from census micro data. They 
concluded that the recent economic performance of European regions is associated with an increase in over-education. Without improving school quality, developing countries will find it difficult to improve their long run economic performance (Hanushek, 2013). (Eigbiremolen, 2014) employs the augmented Solow human-capital-growth model to investigate the impact of human capital development on national output, a proxy for economic growth, using quarterly time- series data from 1999-2012. They found that human capital development has significant positive impact on output level Ordinary Least Square multiple regression to estimate the impact of human capital development on long-run economic growth in Nigeria. (UJUNWA, 2009). They found that the components of human capital development defined by ratio primary education enrollment, ratio of post-primary education enrollment and ratio of tertiary education enrollment are positive but not significant in promoting economic growth in Nigeria. They recommended for the revitalization of Nigerian educational system.

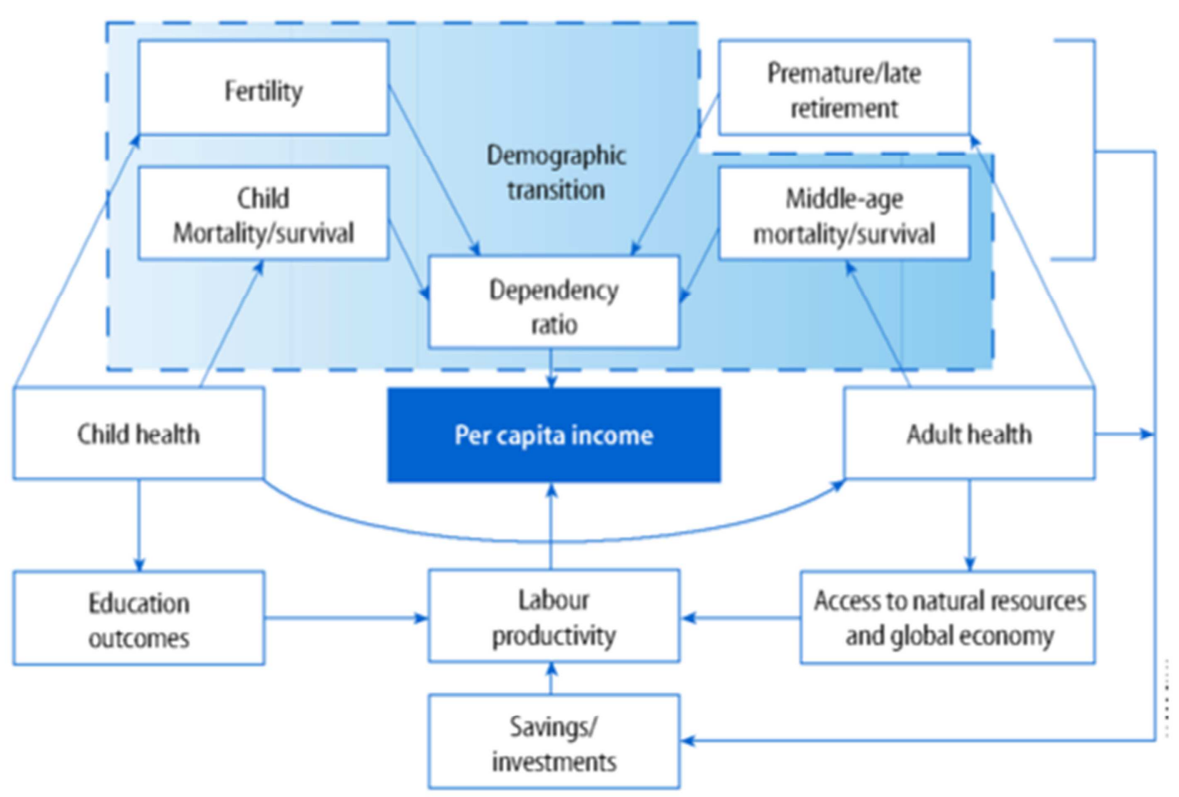

Source: WHO: The World Health Report, 1999, p 11

Figure 4. The Relationship betweenHealth Outcomes and Economic Growth.

(MOHSIN, 2005) asserted that accumulation of physical capital and improvements in the quality of institutions have the largest pay-offs in terms of achieving higher growth, but that better education and health care also have a significant impact. Investment in these areas will increase the possibility of Pakistan entering a virtuous cycle of high growth and improved living conditions for the population. (Maria Javed S. A., 2013) uses co-integration and error correction techniques to examine the relationship between human capital development and economic growth of Pakistan. They found expenditures on health have positive and statistically significant effects on the economic growth rate in the short run. On the other hand, expenditures on education have significantly positive long run impacts. They concluded that there is a good possibility to move forward Pakistan Economy by investing in people in terms of education and health. (Nabila Asghar, 2012) attempts to investigate the role of human capital in terms of education and health on economic growth of Pakistan during 1974-2009. They employed both VECM based causality and Toda-Yamamoto causality tests. They found strong positive impact of human capital on economic growth. They recommended effective economic policies related to the provision of education and health facilities to the people in order to reap maximum benefits from human capital. (Qaisar Abbasa, 2007) used time series data to investigates the relationship between human capital and economic growth in Pakistan. They found aggregate production function results reject the endogenous growth formulation but indicate broadly similar productivity of secondary schooling to that in OECD economies. (Hina Zahra Bokhari, 2013) conducted a research by using random techniques data collection method to analyze the role of health and education on the state's overall development. They found that educated and healthy persons and families were participating more effectively in development of their job specifically and of the region generally as compared to those who were un- educated, less educated or had poor health.

(Rob A. Wilson, 2004) undertook an empirical investigation to determine the links between education and training in a country and its macroeconomic growth. They found a loose correlation between investment in human resources and growth in gross national product (GNP), but clear causal relationships are difficult to establish. Finally, they concluded that the impact of investment in education and training on national economic growth is positive and significant. (Asghar Reza, 2012) investigated the impact of education on economic growth of Pakistan based on an econometric model. They found no correlation between them 
in short run. However, in long run a combination of several factors, including Education contribute towards economic growth. They concluded that the study might be useful for educational sector for policy making and human capital formation to augment economic growth in Pakistan.

(Jones, 1996) used econometric model and the model emphasizes the importance of ideas and technology transfer in addition to capital accumulation. The found that crosscountry data on educational attainment is most appropriately interpreted from the macro stand point as some thing like an investment rate rather than as a capital stock. Governments of Bangladesh and Nepal have been trying to empowering the women by enhancing their capacity, however, they still are left behind. This is mainly due to the governments' insufficient human capital development programs and also due to social, cultural and the economic reasons (Dhakal T.N, Nawaz F. , 2009). (Faisal Sultan Qadri, 2011) in their study found that human capital is positively related to growth and also that the results are robust. In addition, health adjusted education indicator was found to be a highly significant determinant of economic growth.

\section{Data and Methodology}

This study is based on the secondary sources of data. The data are collected for the period of 1979 to 2013. The data for this study are obtained from World Bank data bank (of various years), Bangladesh Bank, Bangladesh economic Review, Bangladesh Statistical Review and World Development Indicators.

To examine the relationship between human capital development and economic growth, We use annual time series data for the period of 1979-2013 for the seven variables GDP per capita (constant 2005 US\$), Gross capital formation (\% of GDP), School enrollment, tertiary (\% gross), School enrollment, secondary (\% gross), School enrollment primary (\% gross), Life expectancy at birth, total (years), Health expenditure, total (\% of GDP), and Government Expenditure for Education.

\subsection{Concepts of Variables Used in the Study}

Gross Domestic Product, per capita: GDP per capita is gross domestic product divided by midyear population. GDP is the sum of gross value added by all resident producers in the economy plus any product taxes and minus any subsidies not included in the value of the products. It is calculated without making deductions for depreciation of fabricated assets or for depletion and degradation of natural resources. Data are in constant 2005 U.S. dollars. This research has taken Gross Domestic Product as a dependent variable in our study.

School Enrollment, Primary (\%of Gross): Gross enrolment ratio. Primary is the total enrollment in primary education, regardless of age, expressed as a percentage of the population of official primary education age. GER can exceed $100 \%$ due to the inclusion of over-aged and under-aged students because of early or late school entrance and grade repetition.
School Enrollment Secondary (\% of Gross): Gross enrolment ratio. Secondary. All programmes. Total is the total enrollment in secondary education, regardless of age, expressed as a percentage of the population of official secondary education age. GER can exceed $100 \%$ due to the inclusion of over-aged and under-aged students because of early or late school entrance and grade repetition.

School enrollment, tertiary (\% gross): Gross enrolment ratio Tertiary (ISCED 5 and 6) total male enrollment in tertiary education (ISCED 5 and 6), regardless of age, expressed as a percentage of the total male population of the five-year age group following on from secondary school leaving.

Life expectancy at birth, total (years): Life expectancy at birth indicates the number of years a newborn infant would live if prevailing patterns of mortality at the time of its birth were to stay the same throughout its life.

Gross Capital Formation: Gross capital formation (formerly gross domestic investment) consists of outlays on additions to the fixed assets of the economy plus net changes in the level of inventories. Fixed assets include land improvements (fences, ditches, drains, and so on); plant, machinery, and equipment purchases; and the construction of roads, railways, and the like, including schools, offices, hospitals, private residential dwellings, and commercial and industrial buildings. Inventories are stocks of goods held by firms to meet temporary or unexpected fluctuations in production or sales, and "work in progress." According to the 1993 SNA, net acquisitions of valuables are also considered capital formation.

Health expenditure, total (\% of GDP): I used total health expenditure as percentage of GDP.

Government expenditure on education, total (\% of GDP): General government expenditure on education (current, capital, and transfers) is expressed as a percentage of GDP. It includes expenditure funded by transfers from international sources to government. General government usually refers to local, regional and central governments.

\subsection{Model Specification}

The primary objective of this study is to estimate the impact of human development on long-run economic growth in Bangladesh. To achieve this objective, the time series Ordinary Least Square multiple regression is used to estimate the model. The functional form of the model is specified as;

$$
\mathrm{Y}_{\mathrm{i}}=\mathrm{B}_{\mathrm{I}}+\mathrm{B}_{2} \mathrm{X}_{2 \mathrm{i}}+\mathrm{B}_{3} \mathrm{X}_{3 \mathrm{i}}+\mathrm{u}_{\mathrm{i}}
$$

Where, $\mathrm{Y}$ is the dependent variable, $\mathrm{X}_{2}$ and $\mathrm{X}_{3}$ are the explanatory variables, $\mathrm{U}$ is the stochastic disturbance term, and $i$ the ith observation since the data is time serial. The basic relationship to estimate is human development indicators and long-run growth version of equation (1), and is of the following form: GDPCapita $=f(G C F$, SET, SES, SEP, $L E, H E, E E, u_{i}$ ). GDPcapita = GDP per capita (constant 2005 US\$),

a) $\mathrm{GCF}=$ Gross capital formation ( $\%$ of GDP), 
b) $\mathrm{SET}=$ School enrollment, tertiary (\% gross),

c) $\mathrm{SES}=$ School enrollment, secondary (\% gross),

d) $\mathrm{SEP}=$ School enrollment, primary ( $\%$ gross $)$,

e) $\mathrm{LE}=$ Life expectancy at birth, total (years),

f) $\mathrm{HE}=$ Health expenditure, total ( $\%$ of GDP),

g) $\mathrm{EE}=$ Government Expenditure on Education (\%of GDP)

School enrollment for primary, secondary and tertiary education institutions in Bangladesh is used as a proxy for human capital development. The inclusion of these three variables is to examine their individual impact on long-run economic growth. The study also controlled other variables that can influences economic growth.

Time serial data of 35 years period: 1979-2013 were collected from World Bank data Bank, Bangladesh Bureau of Statistics, Bangladesh Bank, Asian Development Bank etc. Taking the natural logarithmic of both sides of equation (1) and assuming linearity among the variables give: $\log G D P C a p i t a=f\{\log (G C F, S E T, S E S, S E P, L E, H E, E E$, $\left.\left.u_{i}\right)\right\}$

$$
\log G D P \text { capita }=\propto_{0}+\propto_{1} \log G C F+\propto_{2} \log S E T+\propto_{3} \log S E S+\propto_{4} \log S E P+\propto_{5} \log L E+\propto_{6} \log H E+\propto_{7} \log E E+\in
$$

From the literature, an increase in human capital development should increase economic growth through higher skill acquisition and higher income. Thus, we expect $a$ priori that an increase in primary education enrollment ratio, secondary education enrollment and tertiary education enrollment ratio should increase economic growth. The three human capital development indicators enter the model separately in order to determine which indicator is the best channel through which human capital development influences growth in Bangladesh.

In order to figure out the relationship between Human Capital Development and Economic Growth in Bangladesh, I used the Ordinary Least Square (OLS) as method. The sample period for investigation in 1979-2013 the empirical analysis of this study employed annual secondary data, collected from different sources, which are time series data. Most time series data are non-stationary by their nature. If the data is non-stationary the ordinary least square may not be applicable. So for validity of OLS regression we have applied unit root test to check stationarity. To test the cointegration of variables, Johansson co-integration approach has used. Our empirical analysis can be divided in three stages. The first stage, we used ADF unit root test to test the stationary. In the second stage, the test for co-integration is conducted using Johansson co-integration procedure that is verifies the order of integration of the variables since the various co integration tests are valid only if the variables have the same order of integration and in the final stage, run the regression for the model.

\section{Results and Discussion}

This section presents the statistical and econometric data analysis. Descriptive statistics is the discipline of describing the main quantitative features of data used in study. They give uncomplicated and simple summaries about the data and the measures. It is used for quantitative analysis of data. Descriptive statistics of the variables of our model is given in the Apendix-1.

In Appendix-1, the detailed descriptive analysis was carried out for this analysis which indicates data consists of thirty-five years of annual observation from 1979-2013. The descriptive statistics exhibits that the average of gross domestic product per capita is 5.82 with standard deviation of 0.29 . The average primary school enrollment is 4.47 with standard deviation of 0.17 . The average for school enrollment secondary is 3.48 with the standard deviation of 0.43 . The average for school enrollment tertiary is 1.71 with standard deviation of 0.42 . The average for life expectancy is 4.13 with standard deviation of 0.08 .

The average for health expenditure is 1.07 with the standard deviation of 0.14 . The average for education expenditure is 0.602 with standard deviation of 0.32 . The average for gross capital formation is 3.00 with standard deviation of 0.23 . The result (appendix-2) suggests that there are reasonably positive correlations among all the variables. The results describe that there is strongly positive correlation of lnGDPPC with rest of the variables. Similarly, this is true for rest of the variables. All variables contain strongly positive correlation.

\subsection{Stationary Issues}

A random time series $Y_{t}$ is said to be stationary if its mean and variance constant over time and the value of covariance between two time periods depends only the distance between the two time periods and not on the actual time at which the variance is computed (Gujarti, 1995). In order to check for time series properties stationary of the variables, the widely applied unit root test such as Augmented Dccky -Fuller (1981) has been used.

Table 1. ADF test results for a unit root on the level and first difference of the original series.

\begin{tabular}{|c|c|c|c|c|c|c|c|}
\hline \multirow{2}{*}{ Variables (log term) } & \multicolumn{3}{|c|}{ ADF test at level } & \multicolumn{3}{|c|}{ ADF test at first difference } & \multirow{2}{*}{ Status } \\
\hline & t-statistic & Critical value at $5 \%$ & Decision & t-statistic & Critical value at $5 \%$ & Decision & \\
\hline GDP Capita & 8.257 & -2.975 & stationary & & & & $\mathrm{I}(0)$ \\
\hline GCF & -1.469 & -2.997 & Non-stationary & -0.344 & -2.978 & Non-stationary & NA \\
\hline SET & -0.718 & -2.975 & Non-stationary & -0.314 & -2.978 & Non-stationary & NA \\
\hline SES & -0.925 & -2.975 & Non-stationary & -0.721 & -2.978 & Non-stationary & NA \\
\hline SEP & -0.020 & -2.975 & Non-stationary & -0.178 & -2.978 & Non-stationary & NA \\
\hline
\end{tabular}




\begin{tabular}{|c|c|c|c|c|c|c|c|}
\hline \multirow{2}{*}{ Variables (log term) } & \multicolumn{3}{|c|}{ ADF test at level } & \multicolumn{3}{|c|}{ ADF test at first difference } & \multirow{2}{*}{ Status } \\
\hline & t-statistic & Critical value at $5 \%$ & Decision & t-statistic & Critical value at $5 \%$ & Decision & \\
\hline LE & -9.563 & -2.975 & stationary & & & & $\mathrm{I}(0)$ \\
\hline $\mathrm{HE}$ & -7.266 & -2.975 & stationary & & & & $\mathrm{I}(0)$ \\
\hline $\mathrm{EE}$ & -0.840 & -2.975 & Non-stationary & -2.009 & -2.978 & Non-stationary & NA \\
\hline
\end{tabular}

\subsection{Co-integration Test}

The result obtained for the co-integration test is presented below in table

Rank $0=$ no co-integration among the variables (Null Hypothesis)
There is Co-integration among the variables (Alternative Hypothesis)

Rank $1=$ one con-integration among the variables (Null Hypothesis)

There is Co-integration (Alternative Hypothesis)

Similarly it is true for rest of the rank in this model.

Table 2. Johanson co-integration test co-integration of all the variables series.

\begin{tabular}{llc}
\hline Model & Trace Statistic and Max Statistics & Critical value at 5\% level \\
\hline & $41.3258 \& 32.97$ & $47.21 \& 33.46$ \\
& We cannot reject the null hypothesis rather we accept null hypothesis. There is a long run association-ship among the variables. We \\
& can say there moving together in the long run. There are four co-integrations for Trace Statistic and three co-integrations for Max \\
statistics (see Appen-1).
\end{tabular}

It shows that there is presence of co-integration. The implication of the above result is to estimate initial model, without necessarily resorting to conducting an Error Correction Model.

\subsection{Regression Result}

This research operates two separate models to estimate the relationship between human capital development and economic growth. Table- 3 shows the empirical results obtained from the estimation using time series data for Bangladesh and for the period 1979-2013, using OLS methods.

Table 3. Results of Linear Regression Model forecasting economic growth.

\begin{tabular}{|c|c|c|}
\hline \multirow{2}{*}{ Variables (log term) } & \multicolumn{2}{|c|}{ Regression result, 1979-2013, (TABLE- 5) } \\
\hline & Model (1) & Model (II) \\
\hline \multirow{2}{*}{ GCF } & 0.0195376 & \\
\hline & 0.1732108 & \\
\hline \multirow{2}{*}{ SET } & $0.3374035 * * *$ & $0.3373905^{* * *}$ \\
\hline & 0.0545 & 0.0533855 \\
\hline \multirow{2}{*}{ SES } & $-0.1833195^{*}$ & $-0.1821375^{*}$ \\
\hline & 0.0979194 & 0.0956252 \\
\hline SEP & 0.2492248 & 0.240227 \\
\hline \multirow{2}{*}{ LE } & $2.924742 * *$ & $3.016056^{* * *}$ \\
\hline & 1.192529 & 0.8600807 \\
\hline \multirow{2}{*}{$\mathrm{HE}$} & $-0.2539285^{*}$ & $-0.2594106^{* *}$ \\
\hline & 0.1361589 & 0.1249268 \\
\hline \multirow{2}{*}{$\mathrm{EE}$} & $-0.2739535^{*}$ & $-0.2818765^{*}$ \\
\hline & 0.1524087 & 0.1339573 \\
\hline Constant & 4.04825 & 3.075658 \\
\hline $\mathrm{Nr}$ of Observations & 33 & 33 \\
\hline $\mathrm{R} 2$ & 97.01 & 97.01 \\
\hline $\mathrm{F}$ & 125.21 & 151.42 \\
\hline
\end{tabular}

$* * * \mathrm{p}<0.01, * * \mathrm{p}<0.05, * \mathrm{p}<0.1$

This empirical analysis shows that human capital is a very important conditioning factor of growth in Bangladesh. Human capital enhances productivity, not only through the knowledge or competencies incorporated on individuals but also through the stimulation of physical investment and adoption of technological development.

In model I, most of variables are statistically significant at $1 \%, 5 \%$ and $10 \%$ level except Gross capital formation. In model II, this research excluded this variable from the model as it is statistically insignificant. After excluding gross capital formation from this model, it is ovserved that variables are statistically significant. For this analysis, the final model is model II and both the model consists of high R2 that is about $97.01 \%$.

From the above result the coefficient showed by the constant is negative, proving that there are other factors 
outside this model which negatively related to the economy growth. In other words, a unit change in the intercept will result to 8.78 unit changes in the long-run on the Bangladesh economy. The coefficient of primary and tertiary school enrolment is also positive but secondary school enrollment is negative. It can be said that secondary education in Bangladesh is no longer have positive impact on education. Tertiary education coefficient is positive and it is statistically significant (highly) at $1 \%$ level. This result suggests that the variation in tertiary school enrollment \& primary school enrolment appeared to have a meaningful impact on the growth in Bangladesh economy. In this analysis secondary education coefficient to be negative and also seen that the public expenditure on education and health expenditure coefficient are negative, which is contrary to the a priori expectation. It is concluded that a unit increases in the public education expenditure, on contrary, impacts negatively to economic growth. In other words, public education expenditure has not effectively impacted significantly to economic growth. This is because this variable, apart from the low value of the coefficient, though it is statistically significant because the t-value in absolute value is greater than 2 also. The negative coefficient of the Public expenditure on health showed also negative influence on gross domestic product but it is statistically significant. The variation exhibited by the coefficient of Life Expectancy (LE) has a robust positive coefficient. This implies that the variation in life expectancy has a serious effect on the growth of per capita gross domestic product in the economy. In other words, it shows that a unit increase in life expectancy variable will positively impact to increase by 2.92 units. The responds of this variable is further confirmed by its $\mathrm{t}$-value is greater than 2 in absolute terms at $1 \%$ level of significance, so it is statistically significant. From the model, $\mathrm{R}^{2}=0.9701$, which implies that approximately $97.01 \%$ of the variation in the dependent variable (GDPCapita) is explained by the explanatory variables included in the model and the $F$ value of 151.42 shows that the model has a good fit.

\section{Conclusions}

The main objective of this paper was to investigate the relationship between Human capital development and economic growth of Bangladesh. To attain that objective, unit root test, co-integration and OLS methods were used. The results of this study confirm that all variables are statistically significant as the results are statistically significant mainly in the long run. But some variable like health expenditure and education expenditure coefficient sign are not expected (here it is negative) as research assumed it positive. It is important to note that although the primary school enrolments, life expectancy, tertiary education enrollment government expenditure on health and on education was significantly related to economic growth in Bangladesh, yet our economic growth is not stable and sure so the educational and health sectors should be looked into, and urgent attention should be accorded to these sectors. The human capital development also acts as a catalyst for the improvement of the standard of living of the population. It is also suggested that both quality and quantity of health services and education should be improved so that their effect on the overall economic performance of the nation could be magnified. This study found life expectancy is the most important for economic growth. Life expectancy has increased because recent time Bangladesh Govt. is increasing heath expenditure. Good health and longer live boost the economic growth in Bangladesh. Tertiary education enrollment is statistically significant and has positive coefficient. This is because; recent times a good number of students are enrolling in higher education and good portion of students are going abroad for higher education.

Finally, In this study the human capital development and economic growth has been discussed from the theoretical perspective clearly but In further studies, more pronounced results could be obtained in the area of efficient utilization of public funds allocated to the different sub-sectors (health and education) that constitute human capital development and ways of enhancing human capital contributions to capacity building in Bangladesh.

\section{Appendix}

Appendix 1

\begin{tabular}{r|rrrrr} 
Variable & Obs & Mean & Std. Dev. & Min & Max \\
\hline InGDPPC & 35 & 5.817396 & .2924794 & 5.495162 & $\mathbf{6 . 4 3 1 5 0 1}$ \\
Inprimary & 35 & 4.466806 & .1685796 & 4.188033 & 4.744819 \\
Insecondary & 35 & 3.480448 & .4289592 & 2.804879 & 4.005179 \\
Intertiary & 35 & 1.711879 & .4181698 & 1.097101 & 2.62985 \\
Inlexpecta y & 35 & 4.138977 & .0809383 & 3.990625 & 4.258352 \\
\hline Inhealex & 35 & 1.074617 & .1370809 & .8415037 & 1.315732 \\
Ineduexp & 35 & .6024233 & .320624 & -.0644318 & 1.025977 \\
IncapitaF & 35 & 3.004768 & .2252853 & 2.41626 & 3.346024
\end{tabular}


Appendix 2

\begin{tabular}{|c|c|c|c|c|c|c|c|}
\hline & $\operatorname{lnGDPPC}$ & nprim y & nseco y & ntert y & nlexp y & nhealex & neduexp \\
\hline InGDPPC & 1.0000 & & & & & & \\
\hline Inprimary & 0.9049 & 1.0000 & & & & & \\
\hline Insecondary & 0.8580 & 0.9484 & 1.0000 & & & & \\
\hline lntertiary & 0.9518 & 0.8148 & 0.7819 & 1.0000 & & & \\
\hline lnlexpecta y & 0.9358 & 0.9626 & 0.9546 & 0.8649 & 1.0000 & & \\
\hline Inhealex & 0.7244 & 0.7486 & 0.6381 & 0.7029 & 0.7488 & 1.0000 & \\
\hline lneduexp & 0.8417 & 0.9277 & 0.9486 & 0.7605 & 0.9606 & 0.6529 & 1.0000 \\
\hline \multirow[t]{2}{*}{ IncapitaF } & 0.9220 & 0.8962 & 0.9046 & 0.8649 & 0.9510 & 0.6636 & 0.8797 \\
\hline & Incapi F & & & & & & \\
\hline IncapitaF & 1.0000 & & & & & & \\
\hline
\end{tabular}

Appendix 3

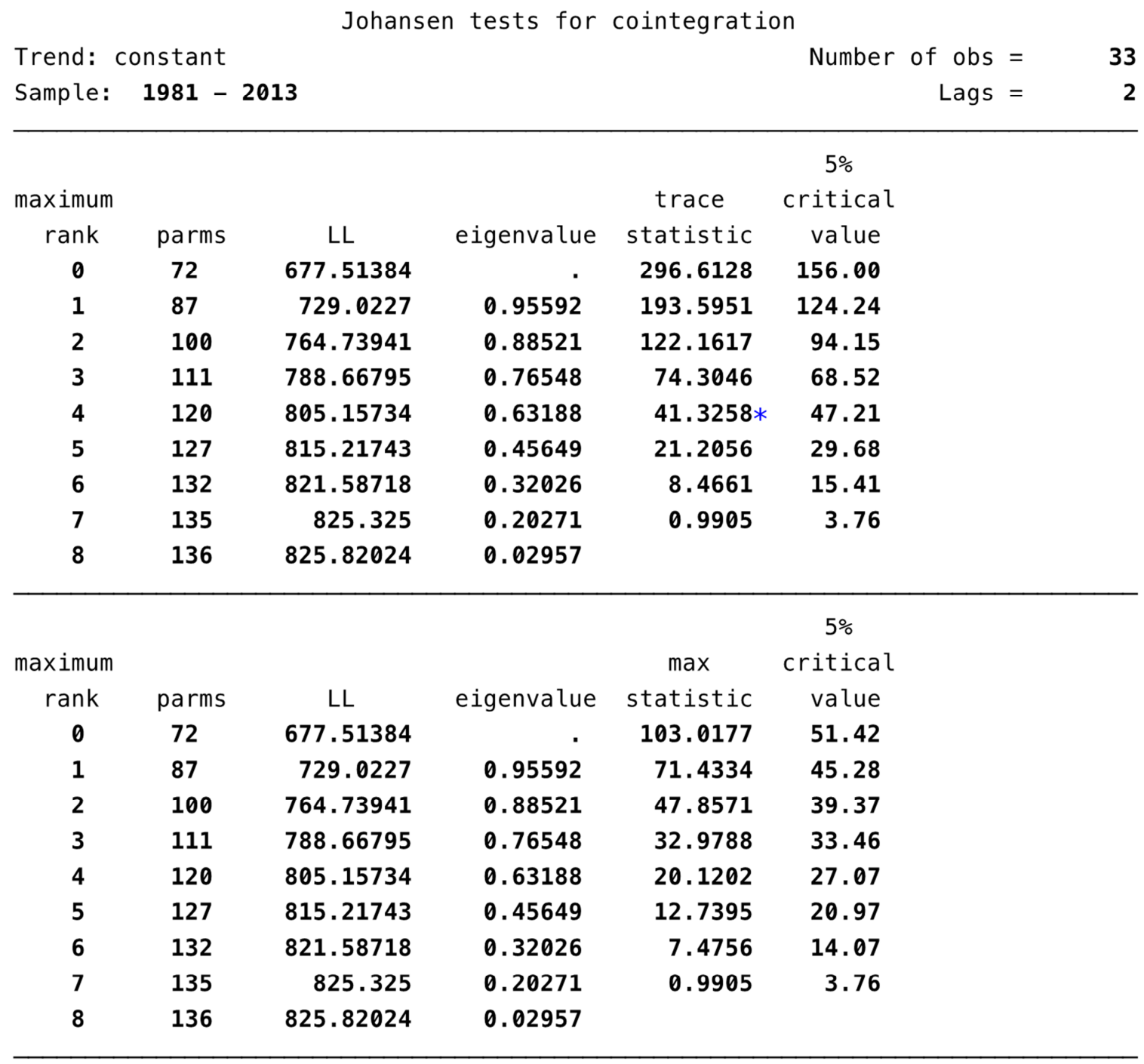




\section{Appendix 4}

- regress InGDPpercap IncapitaF Intertiary Insecondary Inprimary Inlexpectancy Inhealex Ineduex

\begin{tabular}{r|ccccll} 
Source & SS & df & MS & & Number of obs & $=35$ \\
& & & & & &
\end{tabular}

\begin{tabular}{r|rrrrrr}
\hline InGDPpercap & Coef. & Std. Err. & $\mathrm{t}$ & $\mathrm{P}>|\mathrm{t}|$ & [95\% Conf. Interval] \\
\hline IncapitaF & .0195376 & .1732108 & 0.11 & 0.911 & -.3358616 & .3749368 \\
Intertiary & .3374035 & .0545527 & 6.18 & 0.000 & .2254706 & .4493365 \\
Insecondary & -.1833195 & .0979194 & -1.87 & 0.072 & -.3842334 & .0175945 \\
Inprimary & .593218 & .2492248 & 2.38 & 0.025 & .081851 & 1.104585 \\
Inlexpectancy & $\mathbf{2 . 9 2 4 7 4 2}$ & 1.192529 & 2.45 & 0.021 & .4778744 & 5.371611 \\
Inhealex & -.2539285 & .1361589 & -1.86 & 0.073 & -.5333034 & .0254464 \\
Ineduexp & -.2739535 & .1534087 & -1.79 & 0.085 & -.5887222 & .0408152 \\
_cons & -8.49819 & 4.048524 & -2.10 & 0.045 & -16.80507 & -.1913052 \\
\hline
\end{tabular}

\section{Appendix 5}

- regress InGDPpercap Intertiary Insecondary Inprimary Inlexpectancy Inhealex Ineduexp

\begin{tabular}{r|crc} 
Source & SS & df & MS \\
\hline Model & $\mathbf{2 . 8 2 1 5 4 2 8 3}$ & 6 & .470257139 \\
Residual & .086960323 & 28 & .003105726 \\
\hline Total & $\mathbf{2 . 9 0 8 5 0 3 1 6}$ & 34 & .08554421
\end{tabular}

$\begin{array}{lr}\text { Number of obs } & =35 \\ \text { F } 6, \quad 28) & =151.42 \\ \text { Prob }>\text { F } & =0.0000 \\ \text { R-squared } & =0.9701 \\ \text { Adj R-squared } & =0.9637 \\ \text { Root MSE } & =.05573\end{array}$

\begin{tabular}{r|rrrrrr}
\hline InGDPpercap & Coef. & Std. Err. & $\mathrm{t}$ & $\mathrm{P}>|\mathrm{t}|$ & [95\% Conf. Interval] \\
\hline Intertiary & .3379305 & .0533855 & 6.33 & 0.000 & .2285753 & .4472857 \\
Insecondary & -.1821375 & .0956252 & -1.90 & 0.067 & -.3780169 & .0137419 \\
Inprimary & .5878147 & .2402272 & 2.45 & 0.021 & .0957315 & 1.079898 \\
In lexpectancy & 3.016056 & .8600807 & 3.51 & 0.002 & 1.25426 & 4.777851 \\
Inhealex & -.2594106 & .1249268 & -2.08 & 0.047 & -.5153115 & -.0035096 \\
Ineduexp & -.2818765 & .1339573 & -2.10 & 0.044 & -.5562756 & -.0074774 \\
_cons & -8.787643 & 3.075658 & -2.86 & 0.008 & -15.08784 & -2.487444 \\
\hline
\end{tabular}

\section{References}

[1] Abosetegn, M. (2000). Employmrnt Market Information and Occupational Guidance for Tertiary Level Students in Ethiopia: The Case of Prospective Agricultural College Graduates.

[2] Adelakun, O. J. (2011). Human Capital Development and Economic Growth in Nigeria. European Journal of Business and Management, 3(9), 29-38.

[3] Asghar Reza, S. V. (2012, December). Impact of Education on Economic Growth of Pakistan- Econometric Analysis. Journal of Business and Management, 5(4), 20-27.
[4] Bills, M. a. (2000). Does schooling cause growth? American Economic Review, 86(2), 1160-1183.

[5] Chowdhury, M. N., Uddin, M. J., \& Islam, M. S. (2014). An Econometric Analysis of the Determinants of Foreign Exchnage Reserve in Bangladesh. Journal of World Economic Research, 3(6), 72-82. doi: 10.11648/j. jwer.20140306.12.

[6] Development, O. f.-o. (n. d.). Paris: OECD Planning in africa, Addis Abada. UNECA.

[7] Dhakal T. N, Nawaz F.. (2009). Draft Strategy for Improving Human Capital in Bangladesh and Nepal: Does it help for Women Empowerment. Network of Asia-Pacific Schools and Institutes of Public Administration and Governance (NAPSIPAG) Annual Conference Malaysia. 
[8] Eigbiremolen, G. O. (2014, April). Human Capital Development and Economic Growth: The Nigeria Experience. International Journal of Academic Research in Business and Social Sciences, 4(4), 25-35.

[9] Faisal Sultan Qadri, A. W. (2011, November). Human Capital and Economic Growth: Time Series Evidence from Pakistan. PAKISTAN BUSINESS REVIEW.

[10] Galbraith, I. (1996). The new industrial state. Pengium, Harmondsworth.

[11] Galbrith, J. k. (1967). The new industrial state.

[12] Garba, P. (2002). Human Capital Formation, Utilization and the Development of Nigeria. Selected paper for the 2002 Annual Conference of the Nigeria Economic Society. Ibadan Polygraphics Ventures Ltd.

[13] Gazi Mahabubul Alam, M. T. (2009). Return from education system in Bangladesh: An investigation on comparative flashback scenario. African Journal of Business Management, $3(10), 567-575$.

[14] Hanushek, E. A. (2013, April). Economic growth in developing countries: The role of human capital. Economics of Education Review, 37, 204-212.

[15] Hina Zahra Bokhari, A. A. (2013, September). Impact of Education and Health on Economic Development in Pakistan: A Case Study of Multan City. International Journal of Scientific \& Engineering Research, 4(9), 653-659.

[16] Ifeoma C, E. I. (2013, Nov). Human Capital Development and Economic Growth in Nigeria. Journal of Economics and Sustainable Development, 4(18), 48-53.

[17] Jones, C. I. (1996, June). Human Capital, Ideas, and Economic Growth. VIII Villa Mondragone International Economic Seminar on Finance.

[18] Mankiw, N. G. (1992). A Contribution to the Empirics of Economic Growth. The Quarterly Journal of Economics, 107(2).

[19] Maria Javed, S. A. (2013). Impact of Human Capital Development on Economic Growth of Pakistan: A Public Expenditure Approach. World Applied Sciences Journal, 24(3), 408-413.

[20] Maria Javed, S. A. (2013). Impact of Human Capital Development on Economic Growth of Pakistan: A Public Expenditure Approach. World Applied Sciences Journal, 24(3), 408-413.

[21] Md. Mahi Uddin, M. N. (2015, June). Effect of Public Investment on Economic Growth in Bangladesh: An Economietirc Analysis. International Journal of Developing and Emerging Economies, 3(2), 72-97.

[22] MOHSIN, K. S. (2005). Human Capital and Economic Growth in Pakistan. The Pakistan Development Review, 44(4), 455-478.

[23] Nabila Asghar, A. A. (2012). Human Capital and Economic Growth in Pakistan: A Cointegration and Causality Analysis. International Journal of Economics and Finance, 4(4), 135147.
[24] Ojo Oladeji, O. T. (1995). Determinats of Long-Term growth: Some African Results. Journal of African Economics, 4(2).

[25] Olaniyan, D. \&. (2008). Human Capital Theory: Implication for Economic Development. Pakistan Journal of Social Science, 5(5), 479-483.

[26] Poças, A. (2014). HUMAN CAPITAL DIMENSIONS EDUCATION AND HEALTH - AND ECONOMIC GROWTH. Advances in Business-Related Scientific Research Journal, 5(2), 111-120.

[27] Qaisar Abbasa, J. F.-P. (2007, July). Human Capital and Economic Growth: Pakistan, 1960-2003. NRPU projects by Higher Education Commission (HEC) of Pakistan. NRPU projects by Higher Education Commission (HEC) of Pakistan.

[28] RANIS, G. (2000). Economic Growth and Human Development. World Development, 28(2), 197-219.

[29] RAUL RAMOS, J. S. (2012, November). Regional Economic Growth and Human Capital: The Role of Over-education. Regional Studies, 46(10), 1389-1400.

[30] Risikat, D. (n. d.). Role of Human Capital in Economic Development: An Empirical Study of Nigeria Case. rdaduda@unilag.edu.ng.

[31] Rob A. Wilson, G. B. (2004). The impact of human capital on economic growth: a review. Office for Official Publications of the European Communities.

[32] Sajid Ali, I. S. (2012). Human Capital Formation and Economic Growth in Pakistan. Pakistan Journal of Social Sciences, 32(1), 229-240.

[33] Schultz, T. W. (1993). The Economic Importance of Human Capital in Modernization. Education Economics, 1(1), 13-19.

[34] Taimur Sharif, J. A. (2013). Human Resource Development and Economic Growth in Bangladesh: An Econometric Analysis. European Journal of Business and Management, 5(7), 133-144.

[35] U. A. (2009). HUMAN CAPITAL DEVELOPMENT AND ECONOMIC GROWTH: EVIDENCE FROM NIGERIA. International Journal of Development Studies, 4(3), 80-85.

[36] Uddin, M. M., Chowdhury, M. N., \& Uddin, S. (2015, June). Effect of public investment on Economic Growth in Bangldesh: An Econometric Analysis. International Journal of Developing and Emerging Economies, 3(2), 72-97.

[37] Uddin, M., Chowdhuy, N. M., \& Ahmed, M. (2015, 2). Impact of ADP on GDP in Bangladesh: A Cointegration Approach. International Journal of Econometrics and Financial Management, 3(2), 44-56. doi:10. 12691/ijefm-3-2-1

[38] Wakeel A Isola, A. R. (2007). HUMAN CAPITAL DEVELOPMENT AND ECONOMIC GROWTH: EMPIRICAL EVIDENCE FROM NIGERIA. Asian Economic and Financial Review, 2(7), 813-827.

[39] Yeasmin, F., \& Chowdhury, M. N. (2014). Impact of foreign debt on economic growth in Bangladesh: An Econometric Analysis. International Journal of Developing and Emerging Economics, 2(4), 1-23. 